\title{
Oozing Papilloma over an Esophageal Varix: First Report of Endoscopic Band Ligation Treatment
}

\author{
Beatrice Marinoni ${ }^{1}$, Luca Pastorelli ${ }^{1,2}$, Helmut Neumann ${ }^{3}$, Sauid Ishaq ${ }^{4,5}$, Flaminia Cavallaro ${ }^{1}$, Luisa Spina ${ }^{1}$, \\ Maurizio Vecchi ${ }^{1,2}$ and Gian Eugenio Tontini ${ }^{1 *}$ \\ ${ }^{1}$ Gastroenterology \& Digestive Endoscopy Unit, IRCCS Policlinico San Donato, Italy \\ ${ }^{2}$ Department of Biomedical Sciences for Health, University of Milan, Italy \\ ${ }^{3}$ First Medical Department, University Medical Center Mainz, Germany \\ ${ }^{4}$ Department ofGastroenterology, Dudley Group Hospitals \& Birmingham City University, United Kingdom \\ ${ }^{5}$ St. George's University, Grenada, West Indies
}

Submission: November 01, 2017; Published: November 16, 2017

*Corresponding author: Gian Eugenio Tontini, MD, PhD, Gastroenterology \& Digestive Endoscopy Unit, IRCCS Policlinico San Donato, Via Morandi 30, 20097, San Donato Milanese (MI), Italy, Tel: 39 0252774652; Fax: 390252774655; Email: gianeugeniotontini@libero.it

\section{Abstract}

Esophageal papillomas (EPs) are incidentally observed in $0.07 \%$ of patients undergoing endoscopy. Here, we report the case of a 76 -yearold man with a history of Billroth-II gastric resection, chronic anemia, chronic hepatitis C virus infection and alcohol-related cirrhosis with previous endoscopic band ligation (EBL) treatments for esophageal varices (EV). Endoscopy revealed a 4-mm EP on the surface of one residual EV. Despite the indolent appearance of such endoscopic findings, a slightly but persistent oozing occurred from the EP following the endoscope's passage.

Endoscopic therapy was indicated to treat the EP-induced bleeding and remove any growing tissue. A resective-free and ablative-free technique was chosen, targeting the underlying residual EV within the EBL. Given the small size and the stiffness of the underlying residual scarry EV, a second band was released to push the first band deeper into the scar tissue, thereby reducing the risk of band loss and late bleeding. After one-month, no residual EP or EV was observed.

Within this case, we described for the first time the bleeding potential of incidental EP in patients with severe portal hypertension and an easy two-in-one treatment involving the overlying EV with standard EBL.

Keywords: Esophageal papillomas; Endoscopic band ligation; Portal hypertension; Gastrointestinal variceal bleeding

\section{Case Report}

Esophageal papillomas (EPs) are rare endoscopic findings, which are incidentally observed in $0.07 \%$ of patients undergoing endoscopy [1]. EPs are rare benign tumors of the esophagus, which are often solitary. There are few reported cases of EPs in literature. This condition is mostly asymptomatic but dysphagia can be a presenting symptom [2]. Endoscopically, EPs present as pink warty sessile or pedunculated mucosal lesions of the esophagus. The etiology of EPs is not fully understood, although chronic mucosal inflammation and infection with human papilloma viruses are among the possible causative agents. However, the clinical relevance and the natural history of such pre-malignant lesions remain a matter of debate, and the proper management of EPs has not been clarified [3,4]. In fact, different approaches have been reported, which range from interventional endoscopy with ablative and respective treatments to endoscopic surveillance with a still poorly defined strategy. In addition, the underlying presence of esophageal varices due to severe portal hypertension represents a major contraindication to standard resective or ablative endoscopic techniques used for the complete removal of EP, such as cold biopsyor snaire-assisted polypectomy, endoscopic mucosal resection and ablation [4].

Here, we report the case of a 76-year-old man with a history of Billroth II gastric resection, chronic anemia, HCV+ and alcoholrelated cirrhosis with previous endoscopic band ligation (EBL) treatments for esophageal varices. Endoscopy revealed the presence of two residual scarry esophageal varices with a limited bleeding potential. Nonetheless, an incidental EP was observed on the surface of one residual varix placed at 2 o'clock position (Figure 1). The EP presented as whitish-pink, wart-like exophytic projection, which measured 4-mm in diameter. Despite the indolent 
appearance of such endoscopic findings, a slightly but persistent oozing occurred from the EP following the endoscope's passage (Video 1).

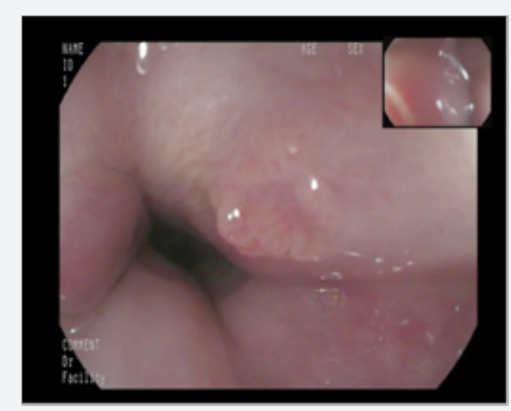

Figure 1: Esophageal papilloma on a residual and scarry esophageal varix following past endoscopic band ligation treatments for severe portal hypertension.

Therefore, endoscopic therapy was indicated to treat the EPinduced bleeding and remove any growing tissue. A resective and ablative-free endoscopic removal technique was chosen, there by targeting the underlying residual esophageal varix within the EBL process (Video 1). The EP surface was completely included in the EBL, which was performed in a standard technique. Given the small size and the stiffness of the underlying residual scarry varix, a second band was released, in order to push the first band deeper into the scar tissue, thereby reducing the risk of band loss and late bleeding. Unfortunately, the EBL removal did not allow to perform the histological examination. However, the EBL technique successfully removed the EP while ligating the esophageal varix and thus treating the EP-induced bleeding. After one-month, the endoscopic control revealed the stigmata of a recent EBL with no residual EP or esophageal varix (Video 1).

This case is interesting for several reasons. For the first time we report on the bleeding potential of incidental EP in patients with severe portal hypertension. Secondly, we describe how such lesion can be successfully and completely removed by standard EBL in an easy two-in-one treatment involving the overlying esophageal varix. Finally, the performance of a new therapeutic technique for EBL is described in detail, providing high-resolution images, which may assist further use of this technique.

\section{References}

1. Mosca S, Manes G, Monaco R, Bellomo PF, Bottino V, et al. (2001) Squamous papilloma of the esophagus: long-term follow up. J Gastroenterol Hepatol 16(8): 857-861.

2. Benisch BM, Mantell C (1974) Multiple squamous papillomas of the esophagus. Arch Otolaryngl 100(5): 379.

3. Kibria R, Akram S, Moezzi J, Ali S (2009) Esophageal squamous papillomatosis with dysplasia. Is there a role of balloon-based radiofrequency ablation therapy? Acta Gastroenterol Belg 72(3): 373-376.

4. Tabatabaei SA, Moghadam NA, Ahmadinejad M, Mirmohammadsadeghi A, Masoudpour H, et al. (2009) Giant esophageal squamous papilloma: a case report. J Dig Dis 10(3): 228-230.

\section{Your next submission with Juniper Publishers will reach you the below assets}

- Quality Editorial service

- Swift Peer Review

- Reprints availability

- E-prints Service

- Manuscript Podcast for convenient understanding

- Global attainment for your research

- Manuscript accessibility in different formats

( Pdf, E-pub, Full Text, Audio)

- Unceasing customer service

\section{Track the below URL for one-step submission}

https://juniperpublishers.com/online-submission.php 